\title{
WORK AMONG DELINQUENT WOMEN AND GIRLS
}

\section{By Henrietta S. Additon,}

Assistant Director, Section on Women and Girls, Law Enforcement Division, W. C. T. C. A.

"For the benefit of those who have forfeited their claims to the respect of the virtuous," reads the charter of a home for girls in one of our large eastern cities.

A well-known social worker describes case work as the art of making clear to the individual the nature of the predicament and what that predicament involves. It continues by showing a way or ways out of the trouble and it concludes by appealing to the motive that will help the person decide to master his predicament and carry out that decision. Until very recently case work as thus described could not possibly have been done for girls who had "lost their virtue" in a community composed largely of the virtuous. Only too well the "fallen women" were made to realize the nature of their predicament; there was no possible way out, for had they not "forfeited their claims," and no amount of motivation on the part of the social worker or good intention on the part of one who had "lost her honor" could find it for her. The inevitable followed, the "ruined girl" soon became a prostitute. Social agencies with case work standards evaded these cases where the way out was so very obscure, and the institutions to which she was referred were usually, like the one whose charter is quoted above, well-meaning; but smugly self-righteous, content to afford the girl shelter while the enormity of her offense was impressed upon her.

Of late years there has been a movement directed toward the prevention of sex offenses on the part of girls. Numerous national organizations, as well as local agencies in many places, are doing excellent work with girls who have not yet crossed the dead line, but once a girl has had sex experience she is rigidly excluded by them all.

But the girl problem has assumed a totally different aspect with the coming of the war. The concentration of a large number of young men in comparatively few places, the tendency of women to flock to the camp towns, the danger of the rapid spread of venereal disease, the unsettled social conditions in these towns, all contributed to force the government into this much shunned field of social work. 
A Committee on Protective Work for Girls was appointed in September, 1917, by Mr. Raymond B. Fosdick, chairman of the War and Navy Departments Commission on Training Camp Activities. The original idea was to throw such safeguards around young girls as would prevent later delinquency. After six months of purely protective work it was found that the serious problem of the camp cities consisted in the already delinquent women and girls.

In April, 1918, the policy was changed and the Section on Women and Girls of the Law Enforcement Division was organized with Mrs. Jane Deeter Rippin in charge, and the section now concentrates on work with women and girls who are sex offenders. Eight supervisors have been appointed for the supervision and extension of this work. Under their direction are placed fixed post workers near the National Army and National Guard camps, Naval Training camps and stations, aviation camps, and in cities where a large number of troops are stationed. Trained women with previous experience in social work have been chosen for these positions.

The Section on Vice and Liquor Control (described elsewhere in this volume), of the Law Enforcement Division of the Commission on Training Camp Activities, has a local representative in every large city. The fixed post worker from the Section on Women and Girls aids him in securing the enforcement of laws against street walking and prostitution, especially assisting in preparation for the prosecution of these cases. When an arrest is made the woman in the case is turned over to her. If possible, an investigation is made before the case is heard in court so that the judge can base his decision on the needs of the particular case. Without this information his decision neither affords protection for society nor reformative treatment for the girl. Much education of judges is needed, but there are a few who are willing to go into these cases deeply and thoroughly, and many others are teachable. Recently a girl of twenty-two was arrested for prostitution in a southern camp town. She claimed to have a father and mother in Indiana and said they would be glad to take her home. The fixed post worker asked that the girl be held until her family could be heard from and some plan made for the future. But the girl was appealing in her tears, so the judge suspended the sentence and told her to go home. About ten days after leaving she wrote a friend in the local jail that she had earned fifty dollars on her way north. There were a number of 
soldiers on her train which was held up by a wreck. While waiting, she had gone to walk with the soldiers. There is no way of estimating how many may have been infected by her. The judge was shown this letter, as well as the attempt to reach her parents which was returned, marked "unable to locate." It was costly but effective education for him.

The Section on Women and Girls assists the Public Health Service in its campaign against venereal disease. Where there is a venereal clinic or any provision for an examination, it is insisted that every girl arrested for a sex offense be examined for venereal disease. In many places there were no facilities for making these examinations and complete reporting to Washington has only recently been organized. Partial reports show that of 5,280 cases of women and girls worked with during the period from October 1 to June $1,1,118$ had venereal disease. How many soldiers and sailors had been infected by each girl it is impossible to estimate, but there is daily evidence that one such woman is a source of danger to hundreds of soldiers. One girl of eighteen was arrested with several soldiers. It was found that her husband who owned an automobile had been taking soldiers to the woods outside of town to meet her. She kept none of the money she received but turned it all over to him. No way of escape seemed possible to her, and her joy at being arrested was pathetic. She was found to be in a badly diseased condition and is under treatment.

It would be impossible to apprehend all the diseased women in the country and lock them up, and even if this were done other prostitutes would doubtless take their places, who would soon become infected. If we are to accomplish anything, we must be able to establish new habits of thought in the minds of these and other women. The peculiar charm and glamour which surrounds the man in uniform causes an unusual type of prostitute to spring up in time of war. Girls idealize the soldier and many really feel that nothing is wrong when done for him. One such girl said that she had never sold herself to a civilian but she felt she was doing her bit when she had been with eight soldiers in a night.

The girls around the large aviation fields in Texas have frequently been heard to say, "I'll do anything these boys ask me to. Don't they face death every day for us?" These girls must be made to realize the dangers that lie in sexual excess to the aviator who 
must have a clear eye, a steady hand and good nerve. Anyone who has done juvenile court work knows that the worst "bad boy" responds when asked to protect or assume responsibility for others. Any of this instinct which may be lying dormant in these women must be appealed to and developed. The strongest element in social case work is mativation. We must give to these women and girls some desire to make good. The best social worker is the one who knows what motive to use in a particular situation and, as pointed out above, there is no field of social work which calls for more resourcefulness, imagination, optimism, and for more individualization than does work with the prostitute.

But all of our sex offenders are not prostitutes, as that term is generally understood. There is the so-called "charity girl"-the girl who goes with the soldier in return for dinners, automobile rides or any present he may give her. She receives no money. In some cases she is the daughter of a well-to-do family. In many others she is the wife of a man who works at night, or is often away from home. She is usually promiscuous and, therefore, usually diseased. Not until increased facilities are available for the physical examination and treatment of diseased girls, and until accurate records are kept, will the truth about the real extent of venereal disease be known.

The most effective personal work among this type of delinquents is that done with the girl who has committed her first sex offense. Young girls are flocking to our camp towns, attracted by the khaki, as well as by stories of the need for workers and the fabulous salaries paid them. They usually find the cost of living is far higher than the salaries paid unskilled workers. Away from home, they live in unattractive rooms, eat cheap insufficient food, and have little money left for recreation, yet many fight on day after day to keep their foothold upon the ladder of respectability. Is it any wonder that the desire for a few of the good things of life proves too much for some of them? When this occurs, if the girl can be reached at once she may be saved from a life of prostitution.

In towns where there is an existing social agency equipped to do intelligent case work with these girls they are referred to it at once. Where there is no such agency the fixed post worker does this personal work herself. If a girl has a proper home she is sent back to it. If not, all the resources of occupation, education, health, 
recreation and religion in the community are brought into play. When an older woman can be found who is willing to take a personal interest in just one such girl, more can be accomplished than in almost any other way. Too much of this work has been attempted in a wholesale fashion.

One thing that has tended to make our work with delinquent girls and women so discouraging is that in most places there have been no facilities for separating the feeble-minded from the normal. Much of our best effort has been put into trying to make mental defectives act like normal human beings, and when this miracle could not be wrought we grew discouraged with the whole project. We should have competent psychologists and institutions for the feeble-minded available in every locality. Because of the lack of these facilities the Committee on Protective Work for Girls received reports on omly 88 girls examined for their mental condition during six months: 42 of these were found to be definitely feebleminded.

Although there have been many sensational stories regarding the large number of pregnant girls who claim soldiers and sailors as fathers of their children, thorough investigations have shown that they are usually based on the experience of one or two girls in the community. Among the 177 illegitimate births reported from camp cities, there are only 84 in which soldiers or sailors in the service are known to be responsible.

Our work is organized primarily for the benefit of the soldier and sailor, to help keep "clean and wholesome the environs of their camps," but we must not forget our duty towards those women and girls who are making this task difficult. All sorts of environmental factors may have entered into their delinquency-poverty, improper parental oversight, bad companions, defective education, uncongenial vocation, bad housing and harmful neighborhood influences. In many cases the physical and mental condition of the offender has been affected by heredity. Now that these facts are recognized, crime has become as much a matter of social responsibility as illiteracy. If, as many people feel, women enter upon the career of prostitution from deliberate choice, there must have been plenty of occupational and recreational opportunity which would have proved interesting. The histories of these girls show that often the cards are hopelessly stacked against them. We read that 
"Alwell W., 20 years old, is a rude, unattractive girl, who uses vile language. She has been living an immoral life for three or four years, has been arrested many times and is considered by the police a hardened character. Says she enjoys her life and wouldn't change for anything." Certainly here seems to be a girl who deserves condemnation, but when we look further we discover these two significant facts in her career. She never went to school a day in her life and she started work in a cotton mill at the age of twelve. Equipped with no education and with childhood memories of long days spent in a cotton mill, should we be shocked at her choice of a life of prostitution?

Nora R., 16, is both deaf and dumb; her mother, who ran a house in the red light district for years, got Nora drunk and forced her to have intercourse with the first man she was ever with. She has a sister who is a prostitute and another on the burlesque stage.

Alina S., 19, left school at ten and started to work in a mill. Said she was tired of working and wanted to make money easily.

Bessie F., 17, prostitute. Family ignorant and low type. Step-father lazy, shiftless, drunkard, who neglects and abuses step-children.

Then there is Marie who has been arrested about twenty-five times in the last two years. She is considered a common prostitute and a very troublesome one at that. But somehow, judgment of this enemy of society softens when we learn she is only 13 years old now, that she began work in a factory when she was nine, and that it was after two years of toil that she preferred a life of prostitution. These are typical cases.

Such of the sections records as are now available show that 6 girls began work at 8 years of age, 16 at 9,20 at 10,18 at 11,44 at 12 , 56 at 13,84 at 14; that 44 never went to school; 7 left school at 8,18 at 9,23 at 10,27 at 11,42 at 12,70 at 13 and 99 at $14 ; 18$ girls stated they had had sex experience from their earliest recollections, 2 at the age of 7, 3 at 9, 6 at 10, 7 at 11, 18 at 12,36 at 13 and 42 at 14.

We have not yet attempted to correlate these three sets of facts or to find out what percentages they constitute of the total number of girls that have come to our attention. The figures are significant because they represent happenings that no community should tolerate even in a single instance.

The personal or case worker is often accused of simply patching 
things up for an individual without in any way changing the conditions that brought about his undoing. On the other hand, it is said of the social reformer that while he is thinking of and planning for a future utopia, he neglects the people who are suffering at his door. The Section on Women and Girls is trying to combine in one person the case worker and the social reformer. In places where these matters have never been thought of before from the community standpoint, her knowledge, accumulated by contact with a series of cases, often proves a revelation, and is the beginning of a movement towards community action. Where there are competent people to handle the case work she devotes all of her time to developing and perfecting the social machinery. As a result of these efforts travelers' aid workers, policewomen and additional probation officers have been secured in many places.

Where possible, local committees are organized to direct the work. Care is taken to choose representative women whose reputations warrant confidence in any movement which they support. Girls' conferences, composed of trained workers with women and girls, meeting with these committees have had very good results. In one such conference the earnestness and sincerity, the freshness of vision shown by some of its members, previously untrained in social work, proved an inspiration to the professional social workers.

Volunteers are being trained in every town to do patrol work. Dance halls, moving picture and cheap burlesque theatres, parks and similar places of amusement are visited regularly and reports of conditions found are sent to Washington, special note being made of the violation of any law or ordinance, the presence of prostitutes, the character of entertainment offered and the general behavior of the people who frequent these places. The conditions in many dance halls were found to be unwholesome, to say the least, as many licentious forms of dancing were common. On the whole, the dance hall managers have been quite willing to help change these conditions when they found someone interested enough to point them out. Quite a few of them are now paying women, approved by the commission's local representative, to supervise their dance halls. Better lighting and policing of parks has also been secured in many places.

The need in almost every camp community for detention places where there is segregation of different classes of offenders and provision for physical examination and care, the necessity of having 
more women and girls committed to institutions for long periods of time, and the lack of reformatories where proper training could be provided, led to the creation of the Section on Detention Homes and Reformatories of the Law Enforcement Division, and plans are now under way to secure the necessary provisions as quickly as possible.

These activities are all being carried on under the direction of the War Commission on Training Camp Activities and is called war work, but it cannot end with the war. The women who are learning now the relation of prostitution and venereal disease to the welfare of their sons and husbands in the training camps will not forget that lesson when the war is over. They can never again accept philosophically what they formerly had shut their eyes to as a necessary evil. These women have heard for the first time the word "prostitution" spoken aloud, they have taken part in public meetings where the subject of commercialized vice has been discussed, and they have heard venereal disease compared to small-pox. Will they permit the resurrection of the restricted vice district?

In its leadership of this new attack on the old problem, the Section on Women and Girls hopes to be able to gather such complete information on each one of these cases that it will be able to isolate a few of the causes, and to find effective remedies and to promote a program for the intelligent and widespread application of treatment. In some instances community action may be necessary in suppressing commercialized vice and the exploitation of children in industry, or in the promoting of public recreation and vocational education. In some instances provision will be necessary for taking an interest in sex offenders, case by case, and studying each one to see what individual weaknesses and defects each presents, and to correct each one in the best possible way.

As a foundation for such study the records of the Section on Women and Girls will in the future tell the story of every girl who comes to them, her age, married at what age, her educational and work history, with whom living, recreations, physical and mental condition, age at first sex experience, reason for court history, men involved, final results; these and many other facts that bear on the case.

The reports from the towns contain the population, kind of industries, and wages paid, number of churches, the clubs which have some influence on the social life of the town; the legitimate oppor- 
tunities for recreation offered; the character of the places of amusement such as dance halls, theatres and parks; the number of saloons; and the violation of the white slave act and marriage of very young girls. Everything that can throw any light on the problem of prostitution is noted.

The War and Navy Departments are a unit in their determination to have a clean army and navy, and to use federal authority to wake up those complacent communities which are willing to see exploited the weaknesses of men and women. For the first time in our history, men in power are sufficiently interested and sympathetic to furnish legislative authority, money and moral support for the realization of ideals so long unheld by people with social vision.

With the responsibility placed squarely on the public where it belongs, and with precedent thus clearly established, may we not look forward to the elimination of at least the grosser forms of vice, within our own generation?

\section{THE SEGREGATION OF DELINQUENT WOMEN AND GIRLS AS A WAR PROBLEM}

\section{By Mrs. Martha P. Falconer,}

Director, Section on Reformatories and Houses of Detention for Women and Girls, Commission on Training Camp Activities.

It has been suggested that the federal government establish four large institutions of industrial training, to be located respectively in the north, central, southern and western sections of the United States, in which to hold, for the period of the war, all girls and women who can be proven in federal court to be a menace to the men in training. At first thought such a drastic, summary measure seems admirable at this time when the country's need requires the greatest possible speed in securing military efficiency.

But setting aside the practical difficulties involved in executing such a plan and dismissing the question of its value socially, the problem of delinquency among women and girls, which we face today as menacing our military strength, is a problem which our awakening social conscience must face, in a lessened degree, in times of peace. So it has seemed to this section that the greatest 